\title{
Ideas and perspectives: on the emission of amines from terrestrial vegetation in the context of new atmospheric particle formation
}

\author{
J. Sintermann and A. Neftel \\ Agroscope Institute for Sustainability Science, Reckenholzstrasse 191, 8046 Zurich, Switzerland \\ Correspondence to: J. Sintermann (sintermann@gmx.ch), A. Neftel (albrecht.neftel@agroscope.admin.ch)
}

Received: 21 December 2014 - Published in Biogeosciences Discuss.: 16 February 2015

Revised: 29 April 2015 - Accepted: 5 May 2015 - Published: 3 June 2015

\begin{abstract}
In this article we summarise recent science which shows how airborne amines, specifically methylamines (MAs), play a key role in new atmospheric particle formation (NPF) by stabilising small molecule clusters. Agricultural emissions are assumed to constitute the most important MA source, but given the short atmospheric residence time of MAs, they can hardly have a direct impact on NPF events observed in remote regions. This leads us to the presentation of existing knowledge focussing on natural vegetationrelated MA sources. High MA contents as well as emissions by plants was already described in the 19th century. Strong MA emissions predominantly occur during flowering as part of a pollination strategy. The behaviour is species-specific, but examples of such species are common and widespread. In addition, vegetative plant tissue exhibiting high amounts of MAs might potentially lead to significant emissions. The decomposition of organic material constitutes another, potentially ubiquitous, source of airborne MAs. These mechanisms would provide sources, which could be crucial for the amine's role in NPF, especially in remote regions. Knowledge about vegetation-related amine emissions is, however, very limited, and thus it is also an open question how global change and the intensified cycling of reactive nitrogen over the last 200 years have altered amine emissions from vegetation with a corresponding effect on NPF.
\end{abstract}

\section{Introduction}

Amines comprise a vast range of nitrogenous organic compounds with aliphatic methylamines (MAs; monomethylamine: MMA; dimethylamine: DMA; trimethylamine: TMA) representing the most common (Ge et al., 2011a) and comparably most studied airborne species. Amines have widely been identified in aerosol particulate matter and wet deposition (Neff et al., 2002; Ge et al., 2011a; Healy et al., 2014; Wang et al., 2015).

New aerosol particle formation (NPF) from gas-phase precursors occurs frequently in the atmosphere, approximately constituting 50 to $80 \%$ of the global aerosol load and 30 to $50 \%$ of cloud condensation nuclei (Merikanto et al., 2009). Estimates of the global secondary aerosol budget are highly uncertain due to uncertainties in gas-phase precursor contributions to NPF and limited mechanistic comprehension (Spracklen et al., 2011). While NPF rates observed in the field do not comply with the classical process understanding involving sulfuric acid (SA) and water (Kirkby et al., 2011; Chen et al., 2012), it has recently become increasingly clear that the ternary system of SA and water, together with neutralising compounds like ammonia $\left(\mathrm{NH}_{3}\right)$ or amines, is a key system in NPF (Chen et al., 2012; Almeida et al., 2013; Kurten et al., 2014). Amines can also form stable molecular clusters with methanesulfonic acid (Dawson et al., 2012). The photochemistry of oxidised organic compounds is another process contributing to NPF with SA. There is currently not sufficient information to assess the combined effect of $\mathrm{NH}_{3}$, amines, and other organics competing in NPF (Riccobono et al., 2014).

Almeida et al. (2013) have shown that, despite their generally low atmospheric concentrations (Ge et al., 2011a), amines play an important role in NPF. Their main finding is that extremely small MA mixing ratios ( $>3$ ppt DMA in their case) suffice to efficiently enhance NPF rates, and that atmospheric observations of NPF rates are only consistently explained taking amines into consideration. This is consistent with the current mechanistic understanding. The NPF 
enhancement by addition of MAs is most significant in situations with clean air, essentially when only little $\mathrm{NH}_{3}$ is present to contribute to SA neutralisation.

The indirect effect of anthropogenic aerosols represents the largest uncertainty in climate radiative forcing according to IPCC (2013). Almeida et al. (2013) note how the recent findings "show that the uncertainty is even greater than previously thought, because extremely low amine emissions which have substantial anthropogenic sources and have not hitherto been considered by the IPCC - have a large influence on the nucleation of sulphuric acid particles. [...] If amine emissions were to spread into pristine regions of the boundary layer where they could switch on nucleation, substantial increases in regional and global cloud condensation nuclei could occur".

In spite of their supposedly important role for NPF, information on the atmospheric abundance and emission pathways of amines remains rather scarce. Further on, we focus on MA as a surrogate for other airborne amines. The most important identified MA sources (Ge et al., 2011a) are agriculture (Schade and Crutzen, 1995; Kuhn et al., 2011; Sintermann et al., 2014), biomass burning (Lobert et al., 1990; Andreae and Merlet, 2001), and the ocean (van Neste et al., 1987; Gorzelska and Galloway, 1990; Wang and Lee, 1994; Gibb et al., 1999b; Facchini et al., 2008). Many marine algae produce MAs (Steiner and Hartmann, 1968; Smith, 1971, 1975), and even remote ocean water contains MA (and the TMA-precursor trimethylamine-N-oxide) (Gibb et al., 1999b, a; Gibb and Hatton, 2004). Such marine amines might represent an important contribution to oceanic secondary aerosol (Myriokefalitakis et al., 2010). As amines are ubiquitous in plant and animal life (Smith, 1971; Dey et al., 1997), terrestrial vegetation is thought to provide another, albeit very weak, source of amines, including MAs (Schade and Crutzen, 1995; Ge et al., 2011a). Towards the end of the 19th century until the 1970s, some authors described high MA abundances associated with tissue and the flowering of certain plant species. This kind of MA source has not yet been elucidated in relation to the discovered key role of amines in NPF.

Here, we summarise the current state of science regarding the importance of amines for NPF and discuss information on the source of MAs from terrestrial vegetation in order to reveal essential research targets and provide important perspectives on the matter. A better understanding of amine emission pathways would help to interpret field observations of NPF and is ultimately required for the description of NPF in chemistry-transport models.

\section{The role of airborne amines in new aerosol particle formation}

Kulmala et al. (2013) describe atmospheric NPF as a mechanism involving three regimes: (1) predominantly neutral molecular clusters (diameter $<1.1$ to $1.3 \mathrm{~nm}$ ) nucleate, but further growth is inhibited because of cluster re-evaporation; (2) the small clusters are efficiently stabilised by combination of SA with a base $\left(\mathrm{NH}_{3} /\right.$ amines) (1.1 to 1.3 to 1.5 to $1.9 \mathrm{~nm}$ ); and (3) these activated clusters (>1.5 to $1.9 \mathrm{~nm}$ ) grow more rapidly by condensation of other vapours and coagulation of clusters. The importance of amines for NPF has recently been established by field (Angelino et al., 2001; Makela et al., 2001; Smith et al., 2010; Zhao et al., 2011) and laboratory experiments (Murphy et al., 2007; Berndt et al., 2010; Erupe et al., 2011; Bzdek et al., 2010; Zhao et al., 2011; Yu et al., 2012; Zollner et al., 2012; Almeida et al., 2013; Jen et al., 2014; Kurten et al., 2014), as well as from modelling studies (Kurten et al., 2008; Barsanti et al., 2009; Bzdek et al., 2010; Ortega et al., 2012; Loukonen et al., 2010; Nadykto et al., 2011; Paasonen et al., 2012; Almeida et al., 2013; DePalma et al., 2014). On a molecular level, Kurten et al. (2014) observed how DMA stabilises SA, increasing the stable cluster concentration by up to 6 orders of magnitude. DMA (and the other MAs) is a stronger base than $\mathrm{NH}_{3}$, which is one of the main reasons for its stabilisation efficiency (Ortega et al., 2012). Compared to the NPF rate caused by SA and 2 to $250 \mathrm{ppt} \mathrm{NH}_{3}$ alone, the enhancement is 3 to 4 orders of magnitude higher in conditions with 5 to 140 ppt DMA and 10 ppt $\mathrm{NH}_{3}$ under SA mixing ratios up to 1 ppt (Almeida et al., 2013). Investigating higher SA mixing ratios (approximately 1-250 ppt), Jen et al. (2014) found an increase in cluster concentration of roughly 2 orders of magnitude, caused by DMA or TMA compared to the maximum caused by $\mathrm{NH}_{3}$ alone. From SA and DMA, Kurten et al. (2014) detected NPF rates close to the collision rate between both molecules, which represents the maximum possible kinetic limit. They argue that collision-rate-driven NPF might be observed only with a DMA concentration higher than a threshold of approximately 100 times the SA concentration, because of cluster coagulation and fission (see Ortega et al., 2012). Accordingly, Almeida et al. (2013) and Jen et al. (2014) identified base concentrations above which the enhancing effect of the alkaline gas species becomes saturated. Then, the NPF rate may proceed at its maximum, which is characteristic for each base. These base threshold concentrations were only 5 to $10 \mathrm{ppt}$ DMA in the experiments of Almeida et al. (2013), and 20 ppt DMA, 30 ppt TMA, 80 to $180 \mathrm{ppt}$ MMA, and 1.1 to $1.8 \mathrm{ppb} \mathrm{NH}$ in the Jen et al. (2014) study. With the base exceeding its (SA-dependent) threshold concentration, the NPF rate solely depends on the availability of SA (Kurten et al., 2014).

In the atmosphere, $\mathrm{SA}$ is continuously formed in situ via oxidation of sulfur dioxide (Boy et al., 2005). Typical SA mixing ratios cover a range from 0.005 to $5 \mathrm{ppt}$ (Eisele and Tanner, 1993; Petäjä et al., 2009; Almeida et al., 2013). Hence, the emissions of the alkaline gases determine, to a large extent, the potential for NPF. In polluted air masses, for example close to intensive agricultural activities or in urban environments, usually enough airborne $\mathrm{NH}_{3}$ and MAs exist 
(Ge et al., 2011a; Sintermann et al., 2014) to favour high NPF rates. The high concentrations of existing particles often hinder NPF by acting as a coagulation sink for newly formed clusters (Kerminen et al., 2001; Dal Maso et al., 2007; Westervelt et al., 2014). In clean pristine air, however, the addition of small amounts of an atmospheric base is expected to promote NPF. This is much more efficient if that base is a MA rather than $\mathrm{NH}_{3}$. Thus, MA emissions in regions with clean air will have a strong impact on NPF - especially when they are not coupled to larger $\mathrm{NH}_{3}$ emissions.

In the environment, the availability of emitted MAs for NPF is constrained by their removal via dry and wet deposition; gas-phase oxidation - mainly by the hydroxyl radical (Ge et al., 2011a; Lee and Wexler, 2013); and condensation onto pre-existing particles. The latter is an efficient removal process yielding a range of MA lifetimes depending on the aerosol number-size distribution and the assumed uptake coefficient (defined as the fraction of molecules being permanently removed from the gas phase by collision with an existing particle). Sintermann et al. (2014) roughly estimate a condensation sink lifetime of TMA of 0.5 and 17 min for a high and lower aerosol burden, respectively, based on an uptake coefficient of 1 . Using a chemistry-transport model, approximating amine emissions by scaling with those of $\mathrm{NH}_{3}$ (the approach taken by Schade and Crutzen, 1995), including oxidation, deposition, and the condensation sink; Yu and Luo (2014) derive atmospheric MA lifetimes. With a maximal uptake coefficient of 0.03 , they calculate atmospheric residence times of approximately $1 \mathrm{~h}$ over Europe, eastern Asia, and the eastern USA, compared to 3 to $>5 \mathrm{~h}$ in more remote regions. Accordingly, modelled MMA, DMA, and TMA concentrations respectively span approximately 5,2, and $10 \mathrm{ppt}$ over India; $2,0.5$, and 5 to 5,1 , and $10 \mathrm{ppt}$ over China and parts of Africa and South America; and 0.2, 0.1, and 0.5 to 2, 0.5, and 5 ppt over the major parts of the other continents to 0.05 , 0.02 , and 0.1 to $0.5,0.2$, and $0.5 \mathrm{ppt}$ in more remote regions (excluding the polar areas). Comparing their results to existing concentration measurements, they suggest, however, that emissions further away from urban areas, and hence concentrations, might be substantially underestimated. This would be emphasized even more strongly by the finding that the estimated agricultural amine emissions do not scale with a constant ratio throughout all $\mathrm{NH}_{3}$ emission stages (Kuhn et al., 2011; Sintermann et al., 2014). In conclusion, the short atmospheric residence time of MAs implies that only local to regional emissions are crucial in promoting NPF. Emissions into clean air would spread the MA potential for NPF further than in situations with higher aerosol burdens.

Measurements of atmospheric MAs are challenging, and reports of concentrations in regions away from potential urban, agricultural, or marine sources are rare. Simultaneous observations of MAs and $\mathrm{NH}_{3}$ and NPF in remote areas would be essential to characterise the corresponding interactions. As far as we know, the only campaigns at comparably remote continental regions have been carried out at the Finnish boreal forest site Hyytiälä (Hari and Kulmala, 2005). Sellegri et al. (2005) found 34 to 80 ppt TMA (and 12 ppt DMA, which was below the detection limit) during a short period in spring 2003, whereas Kieloaho et al. (2013) determined ambient DMA + ethylamine (EA) and TMA + propylamine (PA) from May to October 2011. The highest concentrations of DMA + EA and TMA + PA amounted to $157 \pm 20$ and $102 \pm 60 \mathrm{ppt}$, respectively, in September and October, which were thought to originate from litterfall emissions. DMA +EA exhibited somewhat smaller concentration peaks $(>50 \mathrm{ppt})$ at the beginning of June and in July and August. Diethylamine (DEA) from unassigned sources was also measured and peaked in the summer months $(15.5 \pm 0.5 \mathrm{ppt})$. The observation of NPF events was only moderately correlated to the occurrence of the measured amines. As shown by Hellén et al. (2014), the amines were generally more abundant at the boreal forest site than in the urban environment of Helsinki during the same period. Recent measurements continued to find airborne amines Hyytiälä (Hemmilä et al., 2015). It appears striking that the prevailing amine concentrations at the boreal forest exceeded the threshold values given by Almeida et al. (2013) and Jen et al. (2014) at which the maximum NPF rate could occur. In contrast to the above-mentioned studies, other recent measurements of amines at Hyytiälä, mainly in May 2013, indicate negligible DMA concentrations and no coupling with NPF. On the other hand, traces of TMA + PA and a C4-amine (unquantified) were detected (Sipilä et al., 2015). Schade and Crutzen (1995) estimated an average $\mathrm{MA}: \mathrm{NH}_{3}$ emission ratio of $0.7 \%$ from agricultural sources, which are assumed to dominate the anthropogenic MA source; likewise, Sintermann et al. (2014) measured a maximum TMA emission ratio of $1 \%$. By contrast, simultaneous measurements of MAs and $\mathrm{NH}_{3}$ at a coastal-rural site, with potential marine source influence, indicated timeaveraged concentration ratios DMA : $\mathrm{NH}_{3}=1.6$ to $3.5 \%$ and TMA : $\mathrm{NH}_{3}=0.75$ to $3.9 \%$ (Freshour et al., 2014). In another study at two rural forested areas, the $\mathrm{MA}: \mathrm{NH}_{3}$ ratio did not exceed $1 \%$, but correlation with isoprene led to speculation about a vegetation source (You et al., 2014). The uncertainties of measured gas-phase amines are substantial due to uncertainties in relation to calibration, instrument drift, inlet absorption, gas-to-particle partitioning, and detection interference with other gas species (Freshour et al., 2014; Sipilä et al., 2015). Elevated MA concentrations and higher ratios to $\mathrm{NH}_{3}$ in comparatively remote situation, compared with agricultural environments, could point towards vegetation as another source of MAs. 


\section{Vegetation as a potentially significant source of gas-phase amines}

\subsection{Amines from living plants}

It has been observed that a diverse group of several plant species exhibits exceptionally high amounts of MAs associated either (a) generally with their vegetative tissue (e.g. foliage) or (b) with blossoms during flowering (Smith, 1971, 1975). These species are MA reservoirs representing strong potential MA emitters. Wicke (1862) was among the first to describe the emission of TMA from plants. He observed the occurrence of TMA in condensed transpiration of Chenopodium vulvaria, known for its fish-like smell, which is characteristic of TMA. Remarkably, he saw some kind of "fog" emerging when exposing a $\mathrm{HCl}-$ coated glass rod to the air close to the plant. He might indeed have been the first scientist to witness the effects of NPF from TMA neutralising the acid. At that time it had been known that also pears (Pyrus communis), the hawthorn (Crataegus monogyna), and the rowan (Sorbus aucuparia) contain TMA in their blossoms (Wicke, 1862). Later, the extremely high TMA content of Chenopodium vulvaria was established by Cromwell (1950) and Cromwell and Richards (1966), who followed the works of Power and Chesnut (1925), Vickery (1925), Klein and Steiner (1928), Steiner and Löffler (1929), and Vickery (1932), among others. By then, the range of higher plants with a high MA content in foliage or blossoms had been extended to a few more species. Further on, Stein von Kamienski (1957a, b, 1958) and Steiner (1966) provided measurements comprising the identification of MAs in foliage and especially blossoms of various plants (trees, bushes, herbs), a larger number of fungi, and even some lichen and moss, demonstrating that enrichment of volatile amines is widespread among some families (like Araceae, Caprifoliaceae, Cornaceae, Rosaceae, Umbelliferae) and almost not found in other families (Labiatae, Papilionaceae) (Smith, 1971). Volatile amine abundance is highly species-specific and may depend on phenology and site (Stein von Kamienski, 1957a; Steiner, 1966; Smith, 1971). Smith (1971) reviewed the state of knowledge about amines and plants at that time. MMA, DMA, and TMA have commonly been found in the amine-enriched vegetation. Table A1 (Appendix A) summarises species associated with MAs found in the literature. Some examples of higher plant species, which are widespread in Europe, include Castanea sativa, Cornus sanguinea, Crataegus laevigata, Crataegus monogyna, Mercurialis annua, Mercurialis perennis, Pyrus communis, and Sorbus aucuparia, among others.

It is not entirely clear which pathways lead to MA creation within such plants (Steiner, 1966; Smith, 1971). In principle, formation pathways are the decarboxylation of amino acids and transamination from aldehydes (Cromwell and Richards, 1966; Steiner, 1966; Steiner et al., 1967; Smith, 1971, 1975; Wink and Hartmann, 1981; Dey et al., 1997; Farquhar et al.,
1983; Bagni and Tassoni, 2001; Dudareva et al., 2013). Most measurements addressed the MA content within the tissue of vegetation parts such as fruiting bodies, foliage, and especially blossoms. However, the MAs are also released into the gas phase. Often the characteristic smell was observed, indicating that amines were also being emitted from the living plant. In fact, many plants use the chemical mimicry effect of aminoid fragrances, resembling excrement and decay, in order to attract dung and carrion insects, such as flies and beetles, for pollination. The scents involve a complex composition of many different volatiles with various nitrogencontaining compounds (Dobson, 2006; Abrol, 2012; Woodcock et al., 2014). It has been recognised that MA volatilisation from blossoms plays an important role in that pollination mechanism (Smith, 1971). It might also be that amines serve as antioxidants (Larson, 1988).

At least 15 different amines have been identified as floral scent compounds, and generally the quality and quantity of scents varies spatially and temporally, from plant to plant, and between species (Dudareva and Pichersky, 2006; Knudsen and Gershenzon, 2006). The blossoms are usually, but not necessarily, of white, green, or red-brown colour and often exhibit the characteristic amine odour (Stein von Kamienski, 1957a). One example of plants using MAs as part of a pollination strategy is the hawthorn (here: Crataegus monogyna and Crataegus laevigata). The hawthorn shows the characteristic scent of TMA (El-Sayed, 2014). It is striking that already in medieval times hawthorn branches were a symbol of the Black Death, since the hawthorn's fragrance mimics decay (Vickery, 1995).

Our own dynamic chamber measurements using chemical ionisation mass spectrometry (CIMS) highlight strong TMA emissions from freshly cut twigs with blossoms of Crataegus laevigata and Cornus sanguinea (Fig. 1). These measurements originally had an explorative intention, but we tentatively derive emission estimates. The highest TMA emissions from the approximately 45 Crataegus laevigata blossoms were in the range $0.019-0.038 \mathrm{nmol} \mathrm{s}^{-1}$ and peaked between 0.011 and $0.022 \mathrm{nmol} \mathrm{s}^{-1}$ for Cornus sanguinea (5 umbels). A total of 1000 (as an arbitrary number) blossoms or 100 umbels would thus have emitted up to 0.84 and $0.44 \mathrm{nmol} \mathrm{s}^{-1}$, respectively. As a comparison, the TMA emissions from $1 \mathrm{~m}^{2}$ covered with a mix of farm animal excrement, as a very strong TMA source, have been determined to be of the order of $10 \mathrm{nmol} \mathrm{s}^{-1}$ (Sintermann et al., 2014). It is striking that the $\mathrm{NH}_{3}$ volatilisation from the blossoms is much lower than that of TMA, implying that, in the absence of another significant $\mathrm{NH}_{3}$ source (like agriculture), vegetation-related MA emissions might be an important pathway providing atmospheric bases available for NPF.

The relevance of MA emissions from flowering vegetation for NPF depends on the abundance and phenology of emitting species. One example is Sorbus aucuparia (Stein von Kamienski, 1957a; Richardson, 1966), which is ubiquitous in almost the whole of Europe, including remote northern 

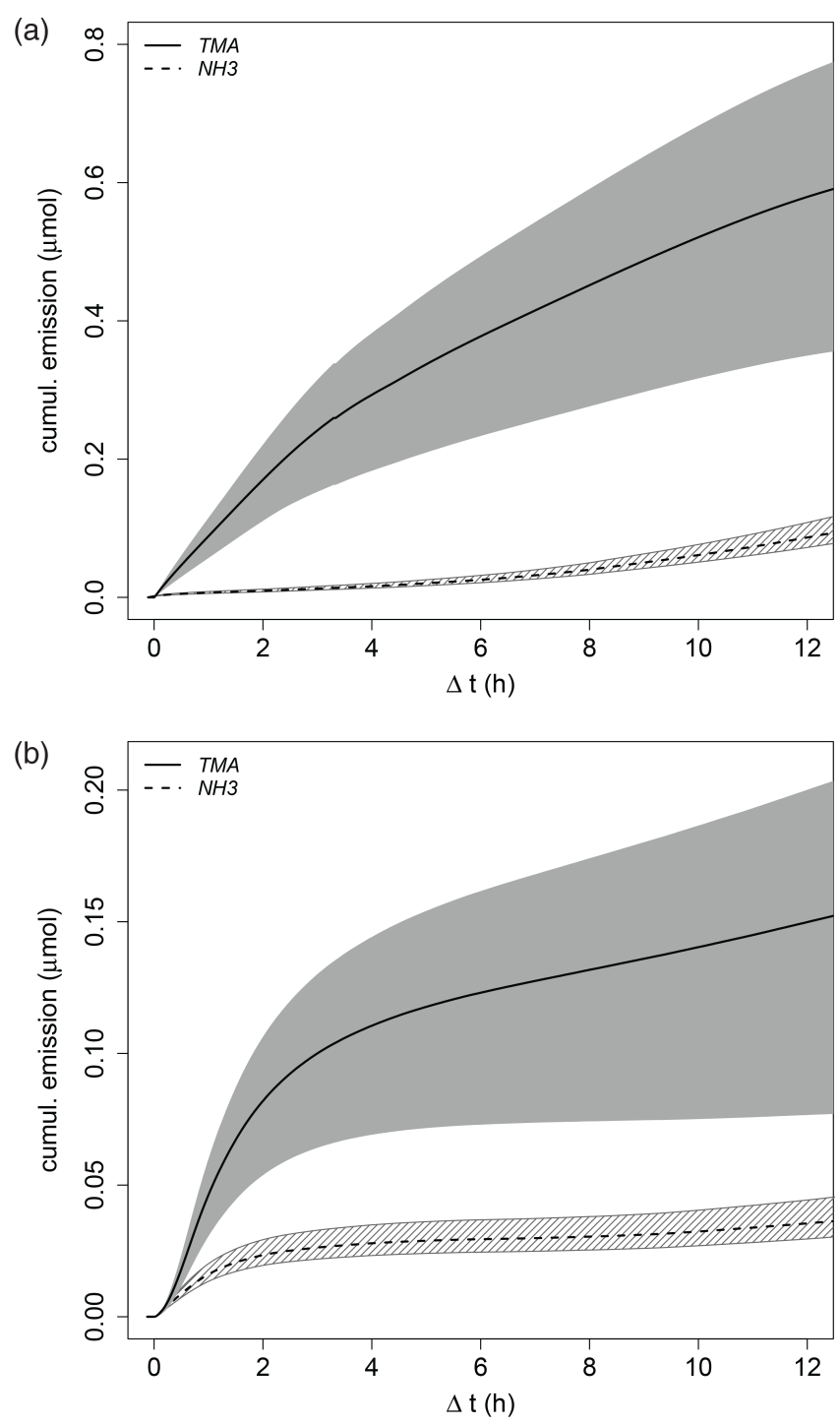

Figure 1. Cumulated TMA and $\mathrm{NH}_{3}$ emissions from blossoms of (a) Crataegus laevigata (approximately 45 blossoms) and (b) Cornus sanguinea ( 5 umbels), determined by dynamic chamber measurements (methods: see Appendix A.).

areas such as Iceland, Finland, and northern Russia. Its habitats stretch south to the mountains of Morocco, over Asia Minor, and it has been introduced to North America. Sorbus aucuparia exhibits a very wide ecological and altitudinal amplitude. In central Europe, it flowers from May to early June. It is found in plant societies that also include Crataegus monogyna and Mercurialis perennis (Raspe et al., 2000) - both species are known as MA carriers (Table A1). Crataegus monogyna commonly grows in Europe and from northern Africa to the Himalaya (Christensen, 1992). Mercurialis perennis grows in many European regions from Norway to the Mediterranean, as well as in northern Africa and the Caucasus from Iran to Russia, and it has been introduced to Australia (Jefferson, 2008). Crataegus monogyna flowers at the end of April and May (Gyan and Woodell, 1987). Mercurialis perennis (wind-pollinated, but with high foliage MA content) can emerge already by January, and females remain aboveground until the first frost in autumn (Jefferson, 2008). These examples illustrate that even just a handful of species could in principle cover extended periods and areas of MA emissions. However, most relevant high emission peaks from individual species will be constrained to a confined time period.

$\mathrm{NH}_{3}$ exchange between the stomata of living plants and the atmosphere is of bi-directional nature. Dissolved $\mathrm{NH}_{3}$ in the apoplast intercellular fluid is in equilibrium with the gas phase, characterised by the ratio $\Gamma=\mathrm{NH}_{4}^{+} / \mathrm{H}^{+}$in solution (Massad et al., 2010b, a; Flechard et al., 2013). The equilibrium air concentration where no net exchange happens is the compensation point (Farquhar et al., 1983; Sutton et al., 1993). The aqueous-to-gas-phase equilibrium depends on the dissociation and Henry's law constants (Ge et al., 2011b). Note that the Henry's law constants of MMA and DMA are in a similar range to that of $\mathrm{NH}_{3}$, but the coefficient for TMA is about 6 times lower (Sander, 1999). The difference in the $\mathrm{pK}_{a}$ value, compared to that of $\mathrm{NH}_{3}$, does not compensate the lower solubility in the case of TMA; i.e. TMA partitions more towards the gas phase than $\mathrm{NH}_{3}$. If there were MAs present in the apoplast, stomatal exchange could contribute to emissions or uptake of MAs in a similar fashion to $\mathrm{NH}_{3}$. To our knowledge this has not yet been investigated.

In this paper, we have focussed on MAs as the most abundant and simplest airborne amines. It has to be kept in mind that volatile amines from vegetation sources comprise a much broader spectrum with identified species such as ethylamine, n-propylamine, isopropylamine, isobutylamine, isoamylamine, and n-hexylamine (Stein von Kamienski, 1957a; Smith, 1971, 1975). Jürgens et al. (2013) note the possibility of convergent evolution of specific VOC emission patterns in angiosperms with chemical mimicry for insects seeking oviposition sites, i.e. mimicry involving odours of animal carrion, decaying plant material, herbivore dung, and omnivore/carnivore faeces. They included only a couple of findings of TMA into their meta-analysis. However, they generally conclude that convergent evolution leads to the use of universal infochemicals which attract insects according to their olfactory adaptations. One can speculate how this suggests that amine-emitting species are more widely spread than the few existing measurements show.

\subsection{Amines from organic matter and fungi}

During the microbial decomposition of organic matter, volatile amines can be formed. Amino acid decarboxylation is featured in the soil (Yan et al., 1996), and, consequently, MAs and other amines are present in dissolved organic nitrogen derived from forest soils (Yu et al., 2002). The liberation of amines, including MMA, has been observed from bacterial cultures (Claeson, 2006). One example of a con- 
trolled and intensified way to degrade organic material is composting. In the headspace of composting facilities high concentrations of amines, especially TMA, have been found (Maris et al., 1999; Mao et al., 2006; Tsai et al., 2008). Emission of $\mathrm{NH}_{3}$ from senescent and decaying plant material has been described, and corresponding $\Gamma$ values have been evaluated (David et al., 2009; Mattsson et al., 2009; Massad et al., 2010a; Flechard et al., 2013). To which extent a similar mechanism also leads to MA emissions in the field needs to be investigated.

The decomposition of decaying organic matter, containing elevated levels of immediate precursor substances for MA, might be a special MA source. One example is choline, which can be efficiently converted to TMA by microbial action (Eddy, 1953; Bain et al., 2005; Craciun and Balskus, 2012). Choline is ubiquitous in plants but occurs more concentrated in some tissue. Beechnuts of Fagus sylvat$i c a$, for instance, contain high amounts of choline (Krauze and Dziedzianowicz, 1959), and Robinia pseudoacacia, Acer platanoides, Acer pseudoplatanus yield high choline concentrations in phloem exudate (Kaiser and Ziegler, 1987). Betaines, which contain TMA, are widely distributed among higher plants, with a couple of species accumulating betaines (Blunden et al., 2005). Polyamines with manifold physiological functions - such as putrescine, spermidine, and spermine - are highly abundant in plants (Moschou et al., 2012).

It is noteworthy that also the fruiting bodies of some common fungi have been found to contain elevated MA levels (Stein von Kamienski, 1958). Indeed, insects act as spore dispersal vectors for fungi, which can produce odours for pollinator attraction (Malloch and Blackwell, 1992). In MAcontaining fungi, Stein von Kamienski (1958) observe a notable increase of MAs when the fruiting bodies decay. Such a source of MA would probably be rather present in autumn.

All these processes are very little studied, and their contribution as a source to gas phase amines is therefore highly uncertain. Emissions are likely very small, but potentially they could be of high importance due to the ubiquitous presence of mineralisation processes.

\section{Context and conclusions}

Contemplating very recent and quite long-standing science, we have presented evidence that terrestrial vegetation, especially during flowering, could constitute an amine source that has the potential to unfold a notable effect on NPF. This kind of source most likely prevails during spring. Potential amine emissions from non-flowering plants, fungi, and decomposing organic matter probably exhibit a wider amplitude during the year, with a probability to intensify towards the autumn. In Scandinavian boreal forests, NPF is a frequent phenomenon occurring approximately during 25 to $50 \%$ of all days. These characteristics exhibit two peaks: one more pronounced during March to May/June and another smaller one around September (Dal Maso et al., 2005, 2007; Kulmala et al., 2012). Biogenic VOC emissions and the corresponding oxidation of terpenoids are thought to influence this pattern (Kulmala et al., 2004). Advection of clean air exhibiting a small condensation and coagulation sink favours NPF events (Dal Maso et al., 2007), which underlines the importance of the contribution of biogenic emission in remote areas. The role of biogenic amine emissions remains speculative; however, amines are considered as key elements in the stabilisation of small clusters, which in turn represents a bottleneck to NPF

Through the invention of the Haber-Bosch process in 1913, humans have greatly intensified the reactive nitrogen $\left(\mathrm{N}_{\mathrm{r}}\right)$ cycle (Galloway et al., 2003) with an increase of the emissions from $13 \mathrm{Tg} \mathrm{Nyr}^{-1}$ in 1860 to $46 \mathrm{Tg} \mathrm{Nyr}^{-1}$ in 1995 and a projection to $82 \mathrm{TgNyr}^{-1}$ in the year 2050 . Even more pronounced is the increase of the production of organic residues from $25 \mathrm{Tg} \mathrm{N} \mathrm{yr}^{-1}$ in 1850 to $125 \mathrm{Tg} \mathrm{Nyr}^{-1}$ in 2000 (Holland et al., 2005). This increase is reflected by an increase of the $\mathrm{N}_{\mathrm{r}}$ deposition on the global scale, even in remote regions (Dentener et al., 2006; Galloway et al., 2008). Since the growth of plants is N-limited in many pristine ecosystems (Vitousek et al., 2002), it has to be assumed that the enhanced $\mathrm{N}$-deposition has increased biomass turnover. It is difficult, however, to determine if and how vegetationrelated MA emissions change due to increased $\mathrm{N}_{\mathrm{r}}$. In principle, accelerated amine formation from decaying organic matter (Sect. 3.2) might co-vary with an accelerated biomass turnover. Large-scale land use change has fundamentally altered vegetation patterns (Lepers et al., 2005; Hansen et al., 2010; Klein Goldewijk et al., 2011). Human-induced climate change can shift vegetation composition, and climate warming affects plant phenology (IPCC, 2014). It is reasonable to expect that such global changes have altered and will continue to impact vegetation-related amine emissions and their potential contribution to NPF. For example, warmer temperatures would shift dissolved amines towards the gas phase with an increased emission potential at liquid-air interfaces. Also, turnover rates of organic matter could be accelerated by higher temperatures. They might also be altered by drought and changes in precipitation. Earlier flowering would change emission seasonality, and vegetation composition change might introduce, enrich, or deplete amine emitting species.

Large knowledge gaps concerning vegetation-related emissions of volatile amines exist. The present discussion illustrates the potential of such emissions for a significant contribution to atmospheric amine concentrations and makes the link towards their relevance for NPF. Here, we have shown that amines and NPF have become more present in current scientific publications. So far, field studies based on measurement techniques with sufficient accuracy, precision, and selectivity to resolve the extremely low ambient concentrations at which amines and NPF begin to interact are almost non-existent (see also Sipilä et al., 2015), but we hope 
that the number of corresponding field experiments will increase. Also, a growing amount of detailed laboratory experiments dedicated to investigating the interaction between amines and NPF have been conducted in recent years (e.g. at the CERN CLOUD chamber). New measurement techniques will lead to a better characterisation of airborne amines and their dynamic behaviour at a limited number of sites. Such techniques include online systems with high selectivity and high sensitivity (like time-of-flight (TOF)-CIMS and atmospheric pressure (AP)-CIMS; e.g. Sipilä et al., 2015) and new developments in ion chromatography (e.g. Hemmilä et al., 2015). Ambient measurements face the challenges of very low concentration levels, distinction between gas and particulate phase, and limited measurement time resolution because of the stickiness of the molecules. Another limitation to an experimental assessment of vegetation-related amine emissions and their atmospheric chemistry and transport is the heterogeneity of sources, resulting in very variable emissions over space and time. This makes a confined quantification very uncertain and not feasible beyond the character of local to regional studies. Presently, the issue of whether the emissions of amines by terrestrial vegetation indeed do have an important impact on NPF and associated alteration of global radiative forcing poses an open research question. 


\section{Appendix A: Figure 1: methods}

Twigs with flowering blossoms (Crataegus laevigata: approximately 45 blossoms; Cornus sanguinea: 5 umbels) were freshly cut from the plant and enclosed in a small dynamic chamber as used by Kuhn et al. (2011), and purged with $0.9 \mathrm{~nL}$ lab air with concentrations of approximately $0 \pm 0.75 \mathrm{ppb}$ TMA and $<7 \pm 1 \mathrm{ppb} \mathrm{NH}_{3}$, respectively. The outflow was sampled into a high-temperature (HT)-CIMS (modified Ionicon PTR-MS in $\mathrm{O}_{2}$ mode as used by Kuhn et al., 2011; Sintermann et al., 2011, 2014) for online analysis of $\mathrm{NH}_{3}$ and TMA. Calibration factors similar to those used by Sintermann et al. (2014) were applied. Here, the uncertainty range was approximated from an estimated systematic uncertainty of $\pm 20 \%$ in the calibration factors, and considering an additional potential $\mathrm{m} / z, 58-\mathrm{m} / z 59$ interference. Emissions were calculated according to Pape et al. (2009). The given range reflects the estimated minimum and maximum systematic uncertainty. Fractionation of higher-weight compounds to $m / z 58$, and thus an undiscovered measurement bias, cannot entirely be ruled out. However, we are not aware of such a measurement artefact, and generally the HTCIMS $m / z 58$ compared reasonably well to the highly specific results of a PTR-TOF-MS during a measurement campaign in animal housing environments (Sintermann et al., 2014). 
Table A1. Literature compilation of MA-enriched species (for another list see Duke and Williams, 1977). Bouchereau et al. (2000) discuss possible measurement uncertainties of amines in plant materials. Some of the older measurements listed in this table might be uncertain due to measurement artefacts.

\begin{tabular}{|c|c|c|c|c|c|}
\hline Species & Investigated & MMA & DMA & TMA & Reference \\
\hline Anthurus muellerianus & fruiting body & $\mathrm{x}$ & & & Stein von Kamienski (1958) \\
\hline Anthurus muellerianus var. aseroeformis & fruiting body & $\mathrm{x}$ & & & Steiner (1966) \\
\hline Arum dioscoridis & condensate in headspace & $\mathrm{x}$ & $\mathrm{x}$ & & Smith and Meeuse (1966) \\
\hline Arum italicum & blossom tissue & $\mathrm{x}$ & & & Stein von Kamienski (1957a) \\
\hline Arum italicum & condensate in headspace & $\mathrm{x}$ & $\mathrm{x}$ & & Smith and Meeuse (1966) \\
\hline Arum maculatum & spadix & $\mathrm{x}$ & $\mathrm{x}$ & & $\begin{array}{l}\text { Klein and Steiner (1928); Stein von Kamienski (1957a); Wink } \\
\text { and Hartmann (1981), but contradicting results: see Kite (1995) }\end{array}$ \\
\hline Atropa belladdona & leave and blossom tissue & $\mathrm{x}$ & & & Stein von Kamienski (1957a) \\
\hline Boletus appendiculatus & fruiting body & $\mathrm{x}$ & & & Stein von Kamienski (1958) \\
\hline Boletus edulis & fruiting body & $\mathrm{x}$ & & & Stein von Kamienski (1958); Steiner (1966) \\
\hline Castanea sativa & blossom odour & & & $\mathrm{x}$ & Porsch (1950) \\
\hline Chaerophyllum aromaticum & blossom tissue & $\mathrm{x}$ & $\mathrm{x}$ & $\mathrm{x}$ & Stein von Kamienski (1957a) \\
\hline Chenopodium vulvaria & leave tissue & & & $\mathrm{x}$ & Stein von Kamienski (1957a); Cromwell and Richards (1966) \\
\hline Chenopodium vulvaria & headspace condensate & & & $\mathrm{x}$ & Wicke (1862) \\
\hline Clathrus ruber & fruiting body & & $\mathrm{x}$ & $\mathrm{x}$ & Stein von Kamienski (1958); Steiner (1966) \\
\hline Claviceps purpurea & sclerotium & $\mathrm{x}$ & $\mathrm{x}$ & $\mathrm{x}$ & Stein von Kamienski (1958) \\
\hline Conium maculatum & blossom tissue & $\mathrm{x}$ & & & Stein von Kamienski (1957a) \\
\hline Cornus sanguinea & blossom tissue & & & $\mathrm{x}$ & Stein von Kamienski (1957a) \\
\hline Crataegus curvisepala & blossom tissue & & & $\mathrm{x}$ & Stein von Kamienski (1957a) \\
\hline Crataegus douglasii & blossom tissue & & & $\mathrm{x}$ & Stein von Kamienski (1957a) \\
\hline Crataegus fecunda & blossom tissue & & & $\mathrm{x}$ & Stein von Kamienski (1957a) \\
\hline Crataegus insperata & blossom tissue & & & $\mathrm{x}$ & Stein von Kamienski (1957a) \\
\hline Crataegus jozana & blossom tissue & & & $\mathrm{x}$ & Stein von Kamienski (1957a) \\
\hline Crataegus laevigata & blossom tissue & & & $\mathrm{x}$ & Stein von Kamienski (1957a) \\
\hline Crataegus mollis & blossom tissue & & & $\mathrm{x}$ & Stein von Kamienski (1957a) \\
\hline Crataegus monogyna & blossom tissue & & & $\mathrm{x}$ & Stein von Kamienski (1957a) \\
\hline Crataegus spinulosa & blossom tissue & & & $\mathrm{x}$ & Stein von Kamienski (1957a) \\
\hline Delphinium consolida & blossom tissue & $\mathrm{x}$ & & & Stein von Kamienski (1957a) \\
\hline Dermocybe (Cortinarius) cinnamomea & fruiting body & $\mathrm{x}$ & & & Stein von Kamienski (1958) \\
\hline Dracunculus vulgaris & headspace condensate & $\mathrm{x}$ & $\mathrm{x}$ & $\mathrm{x}$ & Smith and Meeuse (1966) \\
\hline Geotrichum candidum & arthrospores & & & $\mathrm{x}$ & Maheshwari (2011) and references therein \\
\hline Gingko biloba & fruit tissue & $\mathrm{x}$ & & & Stein von Kamienski (1957a) \\
\hline Heracleum sphondylium & blossom tissue & $\mathrm{x}$ & $\mathrm{x}$ & $\mathrm{x}$ & Stein von Kamienski (1957a) \\
\hline Hydrosme rivieri & headspace condensate & $\mathrm{x}$ & & $\mathrm{x}$ & Smith and Meeuse (1966) \\
\hline Iris germanica & blossom tissue & $\mathrm{x}$ & & & Stein von Kamienski (1957a) \\
\hline Lactarius deliciosus & fruiting body & $\mathrm{x}$ & & & Stein von Kamienski (1958) \\
\hline Lactarius helvus & fruiting body & $\mathrm{x}$ & & & Stein von Kamienski (1958) \\
\hline Lactarius vellereus & fruiting body & $\mathrm{x}$ & & & Stein von Kamienski (1958) \\
\hline Lepiota clypeolaria & fruiting body & $\mathrm{x}$ & & & Stein von Kamienski (1958) \\
\hline Lilium candidum & blossom tissue & $\mathrm{x}$ & & & Stein von Kamienski (1957a) \\
\hline Lilium martagon & blossom tissue & $\mathrm{x}$ & & & Stein von Kamienski (1957a) \\
\hline Lobaria laetevirens & tissue & $\mathrm{x}$ & $\mathrm{x}$ & $\mathrm{x}$ & Smith (1975) and references therein \\
\hline Mercurialis anпиа & leave tissue & $\mathrm{x}$ & & & Stein von Kamienski (1957a) \\
\hline Mercurialis perennis & leave tissue & $\mathrm{x}$ & & & Stein von Kamienski (1957a); Steiner et al. (1967) \\
\hline Musa sapientum & fruit tissue & $\mathrm{x}$ & $\mathrm{x}$ & & Smith (1975) and references therein \\
\hline Mutinus caninus & fruiting body & $\mathrm{x}$ & & & Stein von Kamienski (1958) \\
\hline Nicotiana longiflora & blossom tissue & $\mathrm{x}$ & & & Stein von Kamienski (1957a) \\
\hline Nicotiana paniculata & blossom tissue & $\mathrm{x}$ & & & Stein von Kamienski (1957a) \\
\hline Nicotiana rustica & leave and blossom tissue & $\mathrm{x}$ & & & Stein von Kamienski (1957a) \\
\hline Nicotiana sanderae & blossom tissue & $\mathrm{x}$ & & & Stein von Kamienski (1957a) \\
\hline Nicotiana tabacum & leave and blossom tissue & $\mathrm{x}$ & & & Stein von Kamienski (1957a) \\
\hline Nuphar luteum & blossom tissue & $\mathrm{x}$ & & & Stein von Kamienski (1957a) \\
\hline Phallus impudicus & fruiting body & & $\mathrm{x}$ & $\mathrm{x}$ & Steiner (1966) \\
\hline Philadelphus lemoini & blossom tissue & $\mathrm{x}$ & & & Stein von Kamienski (1957a) \\
\hline Pholiota mutabilis & fruiting body & $\mathrm{x}$ & & & Stein von Kamienski (1958) \\
\hline Pyrus communis & blossom tissue & & & $\mathrm{x}$ & Stein von Kamienski (1957a) \\
\hline Prunus serotina & blossom tissue & & & $\mathrm{x}$ & Stein von Kamienski (1957a) \\
\hline Russula alutacea & fruiting body & $\mathrm{x}$ & $\mathrm{x}$ & $\mathrm{x}$ & Stein von Kamienski (1958) \\
\hline Russula aurata & fruiting body & & $\mathrm{x}$ & & Stein von Kamienski (1958) \\
\hline Russula azurea & fruiting body & $\mathrm{x}$ & & & Stein von Kamienski (1958) \\
\hline Russula cyanoxantha & fruiting body & & $\mathrm{x}$ & & Stein von Kamienski (1958) \\
\hline Russula delica & fruiting body & $\mathrm{x}$ & & & Stein von Kamienski (1958) \\
\hline Russula foetens & fruiting body & $\mathrm{x}$ & & & Stein von Kamienski (1958) \\
\hline Russula grisea & fruiting body & & $\mathrm{x}$ & & Stein von Kamienski (1958) \\
\hline Russula lepida & fruiting body & $\mathrm{x}$ & $\mathrm{x}$ & $\mathrm{x}$ & Stein von Kamienski (1958) \\
\hline Russula maculata & fruiting body & $\mathrm{x}$ & & & Stein von Kamienski (1958) \\
\hline Russula nigricans & fruiting body & & & $\mathrm{x}$ & Stein von Kamienski (1958) \\
\hline Russula ochroleuca & fruiting body & $\mathrm{x}$ & & & Stein von Kamienski (1958) \\
\hline Russula olivacea & fruiting body & & $\mathrm{x}$ & & Stein von Kamienski (1958) \\
\hline
\end{tabular}


Table A1. Continued.

\begin{tabular}{|c|c|c|c|c|c|}
\hline Species & Investigated & MMA & DMA & TMA & Reference \\
\hline Russula pseudodelica & fruiting body & & & $\mathrm{x}$ & Stein von Kamienski (1958) \\
\hline Russula sardonia & fruiting body & $\mathrm{x}$ & $\mathrm{x}$ & & Stein von Kamienski (1958) \\
\hline Russula turci & fruiting body & $\mathrm{x}$ & $\mathrm{x}$ & & Stein von Kamienski (1958) \\
\hline Russula vesca & fruiting body & $\mathrm{x}$ & $\mathrm{x}$ & & Stein von Kamienski (1958) \\
\hline Russula violeipes & fruiting body & $\mathrm{x}$ & & $\mathrm{x}$ & Stein von Kamienski (1958) \\
\hline Russula xerampelina var. barlae & fruiting body & & & $\mathrm{x}$ & Stein von Kamienski (1958) \\
\hline Russula xerampelina var. rubus & fruiting body & & & $\mathrm{x}$ & Stein von Kamienski (1958) \\
\hline Sambucus niger & blossom tissue & $\mathrm{x}$ & & & Stein von Kamienski (1957a) \\
\hline Sauromatum guttatum & headspace condensate & $\mathrm{x}$ & $\mathrm{x}$ & $\mathrm{x}$ & Smith and Meeuse (1966) \\
\hline Scleroderma vulgare & fruiting body & $\mathrm{x}$ & & & Stein von Kamienski (1958) \\
\hline Sorbaria sorbifolia & blossom tissue & & & $\mathrm{x}$ & Stein von Kamienski (1957a) \\
\hline Sorbus aucuparia & blossom tissue & & & $\mathrm{x}$ & Stein von Kamienski (1957a) \\
\hline Splachnum ovatum & tissue & $\mathrm{x}$ & & & Steiner (1966) \\
\hline Staphylea colchica & blossom tissue & $\mathrm{x}$ & & & Stein von Kamienski (1957a) \\
\hline Sticta fuliginosa & tissue & $\mathrm{x}$ & $\mathrm{x}$ & $\mathrm{x}$ & Stein von Kamienski (1958) \\
\hline Sticta limbata & tissue & $\mathrm{x}$ & $\mathrm{x}$ & $\mathrm{x}$ & $\begin{array}{l}\text { Smith (1975) and references } \\
\text { therein }\end{array}$ \\
\hline Sticta sylvatica & tissue & $\mathrm{x}$ & & $\mathrm{x}$ & Stein von Kamienski (1958) \\
\hline Tetraplodon urceolatus & tissue & $\mathrm{x}$ & & & Steiner (1966) \\
\hline Thalictrum flavum & blossom tissue & $\mathrm{x}$ & & & Stein von Kamienski (1957a) \\
\hline Thea sinensis & shoot tissue & $\mathrm{x}$ & & & $\begin{array}{l}\text { Suzuki (1973) (MMA as inter- } \\
\text { mediate } \\
\text { in amino acid metabolism) }\end{array}$ \\
\hline Tilletia tritici & infested ear & & & $\mathrm{x}$ & Stein von Kamienski (1958) \\
\hline Trachypus versipellis & fruiting body & $\mathrm{x}$ & & & Stein von Kamienski (1958) \\
\hline Veratrum nigrum & blossom tissue & $\mathrm{x}$ & & & Stein von Kamienski (1957a) \\
\hline Veratrum opulus & blossom tissue & $\mathrm{x}$ & & & Stein von Kamienski (1957a) \\
\hline Viburnum opulus & blossom tissue & $\mathrm{x}$ & & & Stein von Kamienski (1957a) \\
\hline Xerocomus subtomentosus & fruiting body & & & $\mathrm{x}$ & Stein von Kamienski (1958) \\
\hline
\end{tabular}


Acknowledgements. We are very grateful to Simon Schallhart and Taina Ruuskanen for valuable discussions. We would like to thank Chris Flechard for many helpful remarks. Thanks also go to Andreas Grüning for his advice concerning vegetation-related questions, as well as to Markus Jocher for his assistance with our explorative measurements. J. Sintermann was financially supported by the Swiss Federal Office for the Environment.

Edited by: F. X. Meixner

\section{References}

Abrol, D. P.: Pollination Biology, Springer Netherlands, Dordrecht, 792 pp., 2012.

Almeida, J., Schobesberger, S., Kürten, A., Ortega, I. K., Kupiainen-Määttä, O., Praplan, A. P., Adamov, A., Amorim, A., Bianchi, F., Breitenlechner, M., David, A., Dommen, J., Donahue, N. M., Downard, A., Dunne, E., Duplissy, J., Ehrhart, S., Flagan, R. C., Franchin, A., Guida, R., Hakala, J., Hansel, A., Heinritzi, M., Henschel, H., Jokinen, T., Junninen, H., Kajos, M., Kangasluoma, J., Keskinen, H., Kupc, A., Kurtén, T., Kvashin, A. N., Laaksonen, A., Lehtipalo, K., Leiminger, M., Leppä, J., Loukonen, V., Makhmutov, V., Mathot, S., McGrath, M. J., Nieminen, T., Olenius, T., Onnela, A., Petäjä, T., Riccobono, F., Riipinen, I., Rissanen, M., Rondo, L., Ruuskanen, T., Santos, F. D., Sarnela, N., Schallhart, S., Schnitzhofer, R., Seinfeld, J. H., Simon, M., Sipilä, M., Stozhkov, Y., Stratmann, F., Tomé, A., Tröstl, J., Tsagkogeorgas, G., Vaattovaara, P., Viisanen, Y., Virtanen, A., Vrtala, A., Wagner, P. E., Weingartner, E., Wex, H., Williamson, C., Wimmer, D., Ye, P., Yli-Juuti, T., Carslaw, K. S., Kulmala, M., Curtius, J., Baltensperger, U., Worsnop, D. R., Vehkamäki, H., and Kirkby, J.: Molecular understanding of sulphuric acid-amine particle nucleation in the atmosphere, Nature, 502, 359-363, doi:10.1038/nature12663, 2013.

Andreae, M. O. and Merlet, P.: Emission of trace gases and aerosols from biomass burning, Global Biogeochem. Cy., 15, 955-966, 2001.

Angelino, S., Suess, D. T., and Prather, K. A.: Formation of aerosol particles from reactions of secondary and tertiary alkylamines: characterization by aerosol time-of-flight mass spectrometry, Environ. Sci. Technol., 35, 3130-3138, 2001.

Bagni, N. and Tassoni, A.: Biosynthesis, oxidation and conjugation of aliphatic polyamines in higher plants, Amino Acids, 20, 301317, doi:10.1007/s007260170046, 2001.

Bain, M. A., Fornasini, G., and Evans, A. M.: Trimethylamine: metabolic, pharmacokinetic and safety aspects, Curr. Drug. Metab., 6, 227-240, 2005.

Barsanti, K. C., McMurry, P. H., and Smith, J. N.: The potential contribution of organic salts to new particle growth, Atmos. Chem. Phys., 9, 2949-2957, doi:10.5194/acp-9-2949-2009, 2009.

Berndt, T., Stratmann, F., Sipilä, M., Vanhanen, J., Petäjä, T., Mikkilä, J., Grüner, A., Spindler, G., Lee Mauldin III, R., Curtius, J., Kulmala, M., and Heintzenberg, J.: Laboratory study on new particle formation from the reaction $\mathrm{OH}+\mathrm{SO}_{2}$ : influence of experimental conditions, $\mathrm{H}_{2} \mathrm{O}$ vapour, $\mathrm{NH}_{3}$ and the amine tert-butylamine on the overall process, Atmos. Chem. Phys., 10, 7101-7116, doi:10.5194/acp-10-7101-2010, 2010.
Blunden, G., Patel, A. V., Armstrong, N., Adrian Romero, M., and Meléndez, P.: Betaine distribution in Angiosperms, Biochem. Syst. Ecol., 33, 904-920, doi:10.1016/j.bse.2005.01.005, 2005.

Bouchereau, A., Guénot, P., and Larher, F.: Analysis of amines in plant materials, J. Chromatogr. B, 747, 49-67, 2000.

Boy, M., Kulmala, M., Ruuskanen, T. M., Pihlatie, M., Reissell, A., Aalto, P. P., Keronen, P., Dal Maso, M., Hellen, H., Hakola, H., Jansson, R., Hanke, M., and Arnold, F.: Sulphuric acid closure and contribution to nucleation mode particle growth, Atmos. Chem. Phys., 5, 863-878, doi:10.5194/acp-5-863-2005, 2005.

Bzdek, B. R., Ridge, D. P., and Johnston, M. V.: Amine exchange into ammonium bisulfate and ammonium nitrate nuclei, Atmos. Chem. Phys., 10, 3495-3503, doi:10.5194/acp-10-3495-2010, 2010.

Chen, M., Titcombe, M., Jiang, J., Jen, C., Kuang, C., Fischer, M. L., Eisele, F. L., Siepmann, J. I., Hanson, D. R., Zhao, J., and McMurry, P. H.: Acid-base chemical reaction model for nucleation rates in the polluted atmospheric boundary layer, P. Natl. Acad. Sci. USA, 109, 18713-18718, doi:10.1073/pnas.1210285109, 2012.

Christensen, K. I.: Revision of Crataegus sect. Crataegus and nothosect, in: Crataeguineae (Rosaceae-Maloideae) in the Old World, American Society of Plant Taxonomists, Ann Arbor, Mich., 199 pp., 1992.

Claeson, A.-S.: Volatile organic compounds from microorganisms: identification and health effects, Ph. D. thesis, Univ., Umea, 2006.

Craciun, S. and Balskus, E. P.: Microbial conversion of choline to trimethylamine requires a glycyl radical enzyme, P. Natl. Acad. Sci. USA, 109, 21307-21312, doi:10.1073/pnas.1215689109, 2012.

Cromwell, B.: The micro-estimation and origin of trimethylamine in Chenopodium vulvaria L, Biochem. J., 46, 578-581, 1950.

Cromwell, B. and Richards, M.: Studies on biogenesis of some simple amines and quaternary ammonium compounds in higher plants. Trimethylamine in Chenopodium vulvaria L., Phytochemistry, 5, 735-746, doi:10.1016/S0031-9422(00)83654-7, 1966.

Dal Maso, M., Kulmala, M., Riipinen, I., Wagner, R., Hussein, T., Aalto, P. P., and Lehtinen, K. E.: Formation and growth of fresh atmospheric aerosols: eight years of aerosol size distribution data from SMEAR II, Hyytiälä, Finland, Boreal Environ. Res., 10, 323-366, 2005.

Dal Maso, M., Sogacheva, L., Aalto, P. P., Riipinen, I., Komppula, M., Tunved, P., Korhonen, L., Suur-Uski, V., Hirsikko, A., Kurtén, T., Kerminen, V.-M., Lihavainen, H., Viisanen, Y., Hansson, H.-C., and Kulmala, M.: Aerosol size distribution measurements at four Nordic field stations: identification, analysis and trajectory analysis of new particle formation bursts, Tellus B, 59, 350-361, doi:10.1111/j.1600-0889.2007.00267.x, 2007.

David, M., Loubet, B., Cellier, P., Mattsson, M., Schjoerring, J. K., Nemitz, E., Roche, R., Riedo, M., and Sutton, M. A.: Ammonia sources and sinks in an intensively managed grassland canopy, Biogeosciences, 6, 1903-1915, doi:10.5194/bg-6-19032009, 2009.

Dawson, M. L., Varner, M. E., Perraud, V., Ezell, M. J., Gerber, R. B., and Finlayson-Pitts, B. J.: Simplified mechanism for new particle formation from methanesulfonic acid, amines, and 
water via experiments and ab initio calculations, P. Natl. Acad. Sci. USA, 109, 18719-18724, 2012.

Dentener, F., Drevet, J., Lamarque, J. F., Bey, I., Eickhout, B., Fiore, A. M., Hauglustaine, D., Horowitz, L. W., Krol, M., Kulshrestha, U. C., Lawrence, M., Galy-Lacaux, C., Rast, S., Shindell, D., Stevenson, D., Van Noije, T., Atherton, C., Bell, N., Bergman, D., Butler, T., Cofala, J., Collins, B., Doherty, R., Ellingsen, K., Galloway, J., Gauss, M., Montanaro, V., Mueller, J. F., Pitari, G., Rodriguez, J., Sanderson, M., Solmon, F., Strahan, S., Schultz, M., Sudo, K., Szopa, S., and Wild, O.: Nitrogen and sulfur deposition on regional and global scales: a multimodel evaluation, Global Biogeochem. Cy., 20, GB4003, doi:10.1029/2005GB002672, 2006.

DePalma, J. W., Doren, D. J., and Johnston, M. V.: Formation and Growth of Molecular Clusters Containing Sulfuric Acid, Water, Ammonia, and Dimethylamine, J. Phys. Chem. A, 118, 54645473, doi:10.1021/jp503348b, 2014.

Dey, P. M., Harborne, J. B., and Bonner, J. F.: Plant Biochemistry, Academic Press, San Diego, 554 pp., 1997.

Dobson, H.: Relationship between floral fragrance composition and type of pollinator, in: The Biology of Floral Scent, edited by: Dudareva, N. and Pichersky, E., Taylor and Francis Group, Boca Raton, USA, p. 346, 2006.

Dudareva, N. and Pichersky, E.: Floral scent metabolic pathways: their regulation and evolution, in: The Biology of Floral Scent, edited by: Dudareva, N. and Pichersky, E., Taylor and Francis Group, Boca Raton, USA, p. 346, 2006.

Dudareva, N., Klempien, A., Muhlemann, J. K., and Kaplan, I.: Biosynthesis, function and metabolic engineering of plant volatile organic compounds, New Phytol., 198, 16-32, doi:10.1111/nph.12145, 2013.

Duke, J. A. and Williams, M. C.: Phytotoxin tables, CRC Cr. Rev. Toxicol., 5, 189-237, doi:10.3109/10408447709082600, 1977.

Eddy, B.: Bacterial degradation of choline, Nature, 171, 573-574, doi:10.1038/171573b0, 1953.

Eisele, F. L. and Tanner, D. J.: Measurement of the gas phase concentration of H2SO4 and methane sulfonic acid and estimates of $\mathrm{H} 2 \mathrm{SO} 4$ production and loss in the atmosphere, J. Geophys. Res., 98, 9001, doi:10.1029/93JD00031, 1993.

El-Sayed, A.: The Pherobase: Database of Pheromones and Semiochemicals, available at: http://www.pherobase.com (last access: November 2014), 2014.

Erupe, M. E., Viggiano, A. A., and Lee, S.-H.: The effect of trimethylamine on atmospheric nucleation involving $\mathrm{H}_{2} \mathrm{SO}_{4}$, Atmos. Chem. Phys., 11, 4767-4775, doi:10.5194/acp-11-47672011, 2011.

Facchini, M. C., Decesari, S., Rinaldi, M., Carbone, C., Finessi, E., Mircea, M., Fuzzi, S., Moretti, F., Tagliavini, E., Ceburnis, D., and O'Dowd, C. D.: Important source of marine secondary organic aerosol from biogenic amines, Environ. Sci. Technol., 42, 9116-9121, doi:10.1021/es8018385, 2008.

Farquhar, G. D., Wetselaar, R., and Weir, B.: Gaseous nitrogen losses from plants, in: Gaseous Loss of Nitrogen from Plant-Soil systems, edited by: Freney, J. and Simpson, J., vol. 9 of Developments in Plant Soil Sciences, Springer Sciences+Business Media, Dordrecht, p. 317, 1983.

Flechard, C. R., Massad, R.-S., Loubet, B., Personne, E., Simpson, D., Bash, J. O., Cooter, E. J., Nemitz, E., and Sutton, M. A.: Advances in understanding, models and parameterizations of biosphere-atmosphere ammonia exchange, Biogeosciences, 10, 5183-5225, doi:10.5194/bg-10-5183-2013, 2013.

Freshour, N. A., Carlson, K. K., Melka, Y. A., Hinz, S., Panta, B., and Hanson, D. R.: Amine permeation sources characterized with acid neutralization and sensitivities of an amine mass spectrometer, Atmos. Meas. Tech., 7, 3611-3621, doi:10.5194/amt7-3611-2014, 2014.

Galloway, J. N., Aber, J. D., Erisman, J. W., Seitzinger, S. P., Howarth, R. W., Cowling, E. B., and Cosby, B. J.: The nitrogen cascade, Bioscience, 53, 341-356, 2003.

Galloway, J. N., Townsend, A. R., Erisman, J. W., Bekunda, M., Cai, Z., Freney, J. R., Martinelli, L. A., Seitzinger, S. P., and Sutton, M. A.: Transformation of the nitrogen cycle: recent trends, questions, and potential solutions, Science, 320, 889-892, doi:10.1126/science.1136674, 2008.

Ge, X., Wexler, A. S., and Clegg, S. L.: Atmospheric amines - Part I. A review, Atmos. Environ., 45, 524-546, doi:10.1016/j.atmosenv.2010.10.012, 2011a.

Ge, X., Wexler, A. S., and Clegg, S. L.: Atmospheric amines - Part II. Thermodynamic properties and gas/particle partitioning, Atmos. Environ., 45, 561-577, doi:10.1016/j.atmosenv.2010.10.013, 2011b.

Gibb, S. W. and Hatton, A. D.: The occurrence and distribution of trimethylamine-N-oxide in Antarctic coastal waters, Mar. Chem., 91, 65-75, doi:10.1016/j.marchem.2004.04.005, 2004.

Gibb, S. W., Mantoura, R. C., Liss, P. S., and Barlow, R. G.: Distributions and biogeochemistries of methylamines and ammonium in the Arabian Sea, Deep-Sea Res. Pt. II, 46, 593-615, doi:10.1016/S0967-0645(98)00119-2, 1999a.

Gibb, S. W., Mantoura, R. F. C., and Liss, P. S.: Ocean-atmosphere exchange and atmospheric speciation of ammonia and methylamines in the region of the NW Arabian Sea, Global Biogeochem. Cy., 13, 161-177, 1999b.

Gorzelska, K. and Galloway, J. N.: Amine nitrogen in the atmospheric environment over the North Atlantic Ocean, Global Biogeochem. Cy., 4, 309-333, 1990.

Gyan, K. Y. and Woodell, S. R. J.: Flowering Phenology, Flower colour and mode of reproduction of Prunus spinosa L. (Blackthorn); Crataegus monogyna Jacq. (Hawthorn); Rosa canina L. (Dog Rose); and Rubus fruticosus L. (Bramble) in Oxfordshire, England, Funct. Ecol., 1, 261, doi:10.2307/2389429, 1987.

Hansen, M. C., Stehman, S. V., and Potapov, P. V.: Quantification of global gross forest cover loss, P. Natl. Acad. Sci. USA, 107, 8650-8655, doi:10.1073/pnas.0912668107, 2010.

Hari, P. and Kulmala, M.: Station for measuring ecosystematmosphere relations (SMEAR II), Boreal Environ. Res., 10, 315-322, 2005.

Healy, R. M., Evans, G. J., Murphy, M., Sierau, B., Arndt, J., McGillicuddy, E., O'Connor, I. P., Sodeau, J. R., and Wenger, J. C.: Single-particle speciation of alkylamines in ambient aerosol at five European sites, Anal. Bioanal. Chem., 1-11, doi:10.1007/s00216-014-8092-1, 2014.

Hellén, H., Kieloaho, A.-J., and Hakola, H.: Gas-phase alkyl amines in urban air; comparison with a boreal forest site and importance for local atmospheric chemistry, Atmos. Environ., 94, 192-197, doi:10.1016/j.atmosenv.2014.05.029, 2014.

Hemmilä, M., Hellén, H., Makkonen, U., and Hakola, H.: Amine measurements in boreal forest air, Geophys. Res. Abstr., 17, EGU2015-10480, 2015. 
Holland, E. A., Lee-Taylor, J., Nevison, C., and Sulzman, J. M.: Global $\mathrm{N}$ Cycle: Fluxes and $\mathrm{N}_{2} \mathrm{O}$ Mixing Ratios Originating from Human Activity, Data set, available at: http: //www.daac.ornl.gov, Oak Ridge National Laboratory Distributed Active Archive Center, Oak Ridge, Tennessee, USA, doi:10.3334/ORNLDAAC/797, 2005.

IPCC: Climate Change 2013: the Fifth Assessment Report of the Intergovernmental Panel on Climate Change, edited by: Stocker, T. F., Qin, D., Plattner, G.-K., Tignor, M., Allen, S. K., Boschung, J., Nauels, A., Xia, Y., Bex, V., and Midgley, P. M., Cambridge University Press, Cambridge, United Kingdom and New York, NY, USA, 1535 pp., 2013.

IPCC: Climate Change 2014: Impacts, Adaptation, and Vulnerability, Part A: Global and Sectoral Aspects, of the Intergovernmental Panel on Climate Change, edited by: Field, C. B., Barros, V. R., Dokken, D. J., Mach, K. J., Mastrandrea, M. D., Bilir, T. E., Chatterjee, M., Ebi, K. L., Estrada, Y. O., Genova, R. C., Girma, B., Kissel, E. S., Levy, A. N., MacCracken, S., Mastrandrea, P. R., and White, L. L., Cambridge University Press, Cambridge, United Kingdom and New York, NY, USA, 1132 pp., 2014.

Jefferson, R. G.: Biological flora of the British Isles: Mercurialis perennis L., J. Ecol., 96, 386-412, doi:10.1111/j.13652745.2007.01348.x, 2008.

Jen, C. N., McMurry, P. H., and Hanson, D. R.: Stabilization of sulfuric acid dimers by ammonia, methylamine, dimethylamine, and trimethylamine, J. Geophys. Res.-Atmos., 119, 7502-7514, doi:10.1002/2014JD021592, 2014.

Jürgens, A., Wee, S.-L., Shuttleworth, A., and Johnson, S. D.: Chemical mimicry of insect oviposition sites: a global analysis of convergence in angiosperms, Ecol. Lett., 16, 1157-1167, doi:10.1111/ele.12152, 2013.

Kaiser, K. and Ziegler, H.: Determination of choline in phloem exudates of trees, Trees, 1, 189-190, doi:10.1007/BF00193561, 1987.

Kerminen, V.-M., Pirjola, L., and Kulmala, M.: How significantly does coagulational scavenging limit atmospheric particle production?, J. Geophys. Res., 106, doi:10.1029/2001JD000322, 2001.

Kieloaho, A.-J., Hellén, H., Hakola, H., Manninen, H. E., Nieminen, T., Kulmala, M., and Pihlatie, M.: Gas-phase alkylamines in a boreal Scots pine forest air, Atmos. Environ., 80, 369-377, doi:10.1016/j.atmosenv.2013.08.019, 2013.

Kirkby, J., Curtius, J., Almeida, J., Dunne, E., Duplissy, J., Ehrhart, S., Franchin, A., Gagné, S., Ickes, L., Kürten, A., Kupc, A., Metzger, A., Riccobono, F., Rondo, L., Schobesberger, S., Tsagkogeorgas, G., Wimmer, D., Amorim, A., Bianchi, F., Breitenlechner, M., David, A., Dommen, J., Downard, A., Ehn, M., Flagan, R. C., Haider, S., Hansel, A., Hauser, D., Jud, W., Junninen, H., Kreissl, F., Kvashin, A., Laaksonen, A., Lehtipalo, K., Lima, J., Lovejoy, E. R., Makhmutov, V., Mathot, S., Mikkilä, J., Minginette, P., Mogo, S., Nieminen, T., Onnela, A., Pereira, P., Petäjä, T., Schnitzhofer, R., Seinfeld, J. H., Sipilä, M., Stozhkov, Y., Stratmann, F., Tomé, A., Vanhanen, J., Viisanen, Y., Vrtala, A., Wagner, P. E., Walther, H., Weingartner, E., Wex, H., Winkler, P. M., Carslaw, K. S., Worsnop, D. R., Baltensperger, U., and Kulmala, M.: Role of sulphuric acid, ammonia and galactic cosmic rays in atmospheric aerosol nucleation, Nature, 476, 429-433, doi:10.1038/nature10343, 2011.
Kite, G. C.: The floral odour of Arum maculatum, Biochem. Syst. Ecol., 23, 343-354, 1995.

Klein, G. and Steiner, M.: Stickstoffbasen im Eiweissabbau höherer Pflanzen, I. Ammoniak und flüchtige Amine, Jahr. Wiss. Bot., 68, 602-710, 1928.

Klein Goldewijk, K., Beusen, A., Van Drecht, G., and De Vos, M.: The HYDE 3.1 spatially explicit database of human-induced global land-use change over the past 12000 years: HYDE 3.1 Holocene land use, Global Ecol. Biogeogr., 20, 73-86, doi:10.1111/j.1466-8238.2010.00587.x, 2011.

Knudsen, J. and Gershenzon, J.: The chemical diversity of floral scent, in: The Biology of Floral Scent, edited by: Dudareva, N. and Pichersky, E., Taylor and Francis Group, Boca Raton, USA, p. 346, 2006.

Krauze, S. and Dziedzianowicz, W.: Untersuchungen über die Giftigkeit von Buchensamen (Fagus silvatica L.), Food/Nahrung, 3, 213-227, doi:10.1002/food.19590030305, 1959.

Kuhn, U., Sintermann, J., Spirig, C., Jocher, M., Ammann, C., and Neftel, A.: Basic biogenic aerosol precursors: agricultural source attribution of volatile amines revised, Geophys. Res. Lett., 38, 1-7, doi:10.1029/2011GL047958, 2011.

Kulmala, M., Suni, T., Lehtinen, K. E. J., Dal Maso, M., Boy, M., Reissell, A., Rannik, Ü., Aalto, P., Keronen, P., Hakola, H., Bäck, J., Hoffmann, T., Vesala, T., and Hari, P.: A new feedback mechanism linking forests, aerosols, and climate, Atmos. Chem. Phys., 4, 557-562, doi:10.5194/acp-4-557-2004, 2004.

Kulmala, M., Petäjä, T., Nieminen, T., Sipilä, M., Manninen, H. E., Lehtipalo, K., Dal Maso, M., Aalto, P. P., Junninen, H., Paasonen, P., Riipinen, I., Lehtinen, K. E. J., Laaksonen, A., and Kerminen, V.-M.: Measurement of the nucleation of atmospheric aerosol particles, Nat. Protoc., 7, 1651-1667, doi:10.1038/nprot.2012.091, 2012.

Kulmala, M., Kontkanen, J., Junninen, H., Lehtipalo, K., Manninen, H. E., Nieminen, T., Petaja, T., Sipila, M., Schobesberger, S., Rantala, P., Franchin, A., Jokinen, T., Jarvinen, E., Aijala, M., Kangasluoma, J., Hakala, J., Aalto, P. P., Paasonen, P., Mikkila, J., Vanhanen, J., Aalto, J., Hakola, H., Makkonen, U., Ruuskanen, T., Mauldin, R. L., Duplissy, J., Vehkamaki, H., Back, J., Kortelainen, A., Riipinen, I., Kurten, T., Johnston, M. V., Smith, J. N., Ehn, M., Mentel, T. F., Lehtinen, K. E. J., Laaksonen, A., Kerminen, V.-M., and Worsnop, D. R.: Direct observations of atmospheric aerosol nucleation, Science, 339, 943-946, doi:10.1126/science.1227385, 2013.

Kurten, A., Jokinen, T., Simon, M., Sipila, M., Sarnela, N., Junninen, H., Adamov, A., Almeida, J., Amorim, A., Bianchi, F., Breitenlechner, M., Dommen, J., Donahue, N. M., Duplissy, J., Ehrhart, S., Flagan, R. C., Franchin, A., Hakala, J., Hansel, A., Heinritzi, M., Hutterli, M., Kangasluoma, J., Kirkby, J., Laaksonen, A., Lehtipalo, K., Leiminger, M., Makhmutov, V., Mathot, S., Onnela, A., Petaja, T., Praplan, A. P., Riccobono, F., Rissanen, M. P., Rondo, L., Schobesberger, S., Seinfeld, J. H., Steiner, G., Tome, A., Trostl, J., Winkler, P. M., Williamson, C., Wimmer, D., Ye, P., Baltensperger, U., Carslaw, K. S., Kulmala, M., Worsnop, D. R., and Curtius, J.: Neutral molecular cluster formation of sulfuric acid-dimethylamine observed in real time under atmospheric conditions, P. Natl. Acad. Sci. USA, 111, 15019-15024, doi:10.1073/pnas.1404853111, 2014. 
Kurtén, T., Loukonen, V., Vehkamäki, H., and Kulmala, M.: Amines are likely to enhance neutral and ion-induced sulfuric acid-water nucleation in the atmosphere more effectively than ammonia, Atmos. Chem. Phys., 8, 4095-4103, doi:10.5194/acp-8-4095-2008, 2008.

Larson, R.: The antioxidants of higher-plants, Phytochemistry, 27, 969-978, 1988.

Lee, D. and Wexler, A. S.: Atmospheric amines - Part III: Photochemistry and toxicity, Atmos. Environ., 71, 95-103, doi:10.1016/j.atmosenv.2013.01.058, 2013.

Lepers, E., Lambin, E. F., Janetos, A. C., DeFries, R., Achard, F., Ramankutty, N., and Scholes, R. J.: A synthesis of information on rapid land-cover change for the period 1981-2000, Bioscience, 55, 115-124, 2005.

Lobert, J. M., Scharfe, D. H., Hao, W. M., and Crutzen, P. J.: Importance of biomass burning in the atmospheric budgets of nitrogen containing gases, Nature, 346, 552-554, 1990.

Loukonen, V., Kurtén, T., Ortega, I. K., Vehkamäki, H., Pádua, A. A. H., Sellegri, K., and Kulmala, M.: Enhancing effect of dimethylamine in sulfuric acid nucleation in the presence of water - a computational study, Atmos. Chem. Phys., 10, 49614974, doi:10.5194/acp-10-4961-2010, 2010.

Maheshwari, D. K. (Ed.): Bacteria in Agrobiology: Plant Nutrient Management, Springer, Berlin, Heidelberg, 345 pp., 2011.

Makela, J. M., Yli-Koivisto, S., Hiltunen, V., Seidl, W., Swietlicki, E., Teinila, K., Sillanpaa, M., Koponen, I. K., Paatero, J., Rosman, K., and Hameri, K.: Chemical composition of aerosol during particle formation events in boreal forest, Tellus B, 53, 380-393, 2001.

Malloch, D. and Blackwell, M.: Dispersal of fungal diaspores, in: The Fungal Community: Its Organization and Role in the Ecosystem, edited by: Carroll, G. and Wicklow, D., Marcel Dekker, New York, 2nd edn., 952 pp., 1992.

Mao, I.-F., Tsai, C.-J., Shen, S.-H., Lin, T.-F., Chen, W.-K., and Chen, M.-L.: Critical components of odors in evaluating the performance of food waste composting plants, Sci. Total Environ., 370, 323-329, doi:10.1016/j.scitotenv.2006.06.016, 2006.

Maris, C., Laplanche, A., Morvan, J., and Bloquel, M.: Static headspace analysis of aliphatic amines in aqueous samples, J. Chromatogr. A, 846, 331-339, doi:10.1016/S00219673(99)00403-3, 1999.

Massad, R.-S., Nemitz, E., and Sutton, M. A.: Review and parameterisation of bi-directional ammonia exchange between vegetation and the atmosphere, Atmos. Chem. Phys., 10, 10359-10386, doi:10.5194/acp-10-10359-2010, 2010a.

Massad, R.-S., Tuzet, A., Loubet, B., Perrier, A., and Cellier, P.: Model of stomatal ammonia compensation point (STAMP) in relation to the plant nitrogen and carbon metabolisms and environmental conditions, Ecol. Model., 221, 479-494, doi:10.1016/j.ecolmodel.2009.10.029, 2010b.

Mattsson, M., Herrmann, B., David, M., Loubet, B., Riedo, M., Theobald, M. R., Sutton, M. A., Bruhn, D., Neftel, A., and Schjoerring, J. K.: Temporal variability in bioassays of the stomatal ammonia compensation point in relation to plant and soil nitrogen parameters in intensively managed grassland, Biogeosciences, 6, 171-179, doi:10.5194/bg-6-171-2009, 2009.

Merikanto, J., Spracklen, D. V., Mann, G. W., Pickering, S. J., and Carslaw, K. S.: Impact of nucleation on global CCN, At- mos. Chem. Phys., 9, 8601-8616, doi:10.5194/acp-9-8601-2009, 2009.

Moschou, P. N., Wu, J., Cona, A., Tavladoraki, P., Angelini, R., and Roubelakis-Angelakis, K. A.: The polyamines and their catabolic products are significant players in the turnover of nitrogenous molecules in plants, J. Exp. Bot., 63, 5003-5015, doi:10.1093/jxb/ers202, 2012.

Murphy, S. M., Sorooshian, A., Kroll, J. H., Ng, N. L., Chhabra, P., Tong, C., Surratt, J. D., Knipping, E., Flagan, R. C., and Seinfeld, J. H.: Secondary aerosol formation from atmospheric reactions of aliphatic amines, Atmos. Chem. Phys., 7, 2313-2337, doi:10.5194/acp-7-2313-2007, 2007.

Myriokefalitakis, S., Vignati, E., Tsigaridis, K., Papadimas, C., Sciare, J., Mihalopoulos, N., Facchini, M. C., Rinaldi, M., Dentener, F. J., Ceburnis, D., Hatzianastasiou, N., O’Dowd, C. D., van Weele, M., and Kanakidou, M.: Global modeling of the oceanic source of organic aerosols, Adv. Meteorol., 2010, 1-16, doi:10.1155/2010/939171, 2010.

Nadykto, A., Yu, F., Jakovleva, M., Herb, J., and Xu, Y.: Amines in the Earth's atmosphere: a density functional theory study of the thermochemistry of pre-nucleation clusters, Entropy, 13, 554569, doi:10.3390/e13020554, 2011.

Neff, J. C., Holland, E. A., Dentener, F. J., McDowell, W. H., and Russell, K. M.: The origin, composition and rates of organic nitrogen deposition: a missing piece of the nitrogen cycle?, Biogeochemistry, 57, 99-136, 2002.

Ortega, I. K., Kupiainen, O., Kurtén, T., Olenius, T., Wilkman, O., McGrath, M. J., Loukonen, V., and Vehkamäki, H.: From quantum chemical formation free energies to evaporation rates, Atmos. Chem. Phys., 12, 225-235, doi:10.5194/acp-12-225-2012, 2012.

Paasonen, P., Olenius, T., Kupiainen, O., Kurtén, T., Petäjä, T., Birmili, W., Hamed, A., Hu, M., Huey, L. G., Plass-Duelmer, C., Smith, J. N., Wiedensohler, A., Loukonen, V., McGrath, M. J., Ortega, I. K., Laaksonen, A., Vehkamäki, H., Kerminen, V.-M., and Kulmala, M.: On the formation of sulphuric acid - amine clusters in varying atmospheric conditions and its influence on atmospheric new particle formation, Atmos. Chem. Phys., 12, 9113-9133, doi:10.5194/acp-12-9113-2012, 2012.

Pape, L., Ammann, C., Nyfeler-Brunner, A., Spirig, C., Hens, K., and Meixner, F. X.: An automated dynamic chamber system for surface exchange measurement of non-reactive and reactive trace gases of grassland ecosystems, Biogeosciences, 6, 405429, doi:10.5194/bg-6-405-2009, 2009.

Petäjä, T., Mauldin, III, R. L., Kosciuch, E., McGrath, J., Nieminen, T., Paasonen, P., Boy, M., Adamov, A., Kotiaho, T., and Kulmala, M.: Sulfuric acid and $\mathrm{OH}$ concentrations in a boreal forest site, Atmos. Chem. Phys., 9, 7435-7448, doi:10.5194/acp9-7435-2009, 2009.

Porsch, O.: Geschichtliche Lebenswertung der Kastanienblüte, Osterr. Bot. Z., 97, 269-321, doi:10.1007/BF01763311, 1950.

Power, B. and Chesnut, V.: The odorous constituents of the cotton plant. Examination of ammonia and trimethylamine from the living plant, J. Am. Chem. Soc., 47, 1751-1774, 1925.

Raspe, O., Findlay, C., and Jacquemart, A.-L.: Sorbus aucuparia L., J. Ecol., 88, 910-930, doi:10.1046/j.1365-2745.2000.00502.x, 2000.

Riccobono, F., Schobesberger, S., Scott, C. E., Dommen, J., Ortega, I. K., Rondo, L., Almeida, J., Amorim, A., Bianchi, F., 
Breitenlechner, M., David, A., Downard, A., Dunne, E. M., Duplissy, J., Ehrhart, S., Flagan, R. C., Franchin, A., Hansel, A., Junninen, H., Kajos, M., Keskinen, H., Kupc, A., Kurten, A., Kvashin, A. N., Laaksonen, A., Lehtipalo, K., Makhmutov, V., Mathot, S., Nieminen, T., Onnela, A., Petaja, T., Praplan, A. P., Santos, F. D., Schallhart, S., Seinfeld, J. H., Sipila, M., Spracklen, D. V., Stozhkov, Y., Stratmann, F., Tome, A., Tsagkogeorgas, G., Vaattovaara, P., Viisanen, Y., Vrtala, A., Wagner, P. E., Weingartner, E., Wex, H., Wimmer, D., Carslaw, K. S., Curtius, J., Donahue, N. M., Kirkby, J., Kulmala, M., Worsnop, D. R., and Baltensperger, U.: Oxidation products of biogenic emissions contribute to nucleation of atmospheric particles, Science, 344, 717-721, doi:10.1126/science.1243527, 2014.

Richardson, M.: Studies on the biogenesis of some simple amines and quaternary ammonium compounds in higher plants, Phytochemistry, 5, 23-30, doi:10.1016/S0031-9422(00)85078-5, 1966.

Sander, R.: Compilation of Henry's Law Constants for Inorganic and Organic Species of Potential Importance in Environmental Chemistry, available at: http://www.mpch-mainz.mpg.de/ $\sim$ sander/res/henry.html (last access: December 2014), 1999.

Schade, G. W. and Crutzen, P. J.: Emission of aliphatic amines from animal husbandry and their reactions - potential source of $\mathrm{N}_{2} \mathrm{O}$ and HCN, J. Atmos. Chem., 22, 319-346, 1995.

Sellegri, K., Umann, B., Hanke, M., and Arnold, F.: Deployment of a ground-based CIMS apparatus for the detection of organic gases in the boreal forest during the QUEST campaign, Atmos. Chem. Phys., 5, 357-372, doi:10.5194/acp-5-357-2005, 2005.

Sintermann, J., Spirig, C., Jordan, A., Kuhn, U., Ammann, C., and Neftel, A.: Eddy covariance flux measurements of ammonia by high temperature chemical ionisation mass spectrometry, Atmos. Meas. Tech., 4, 599-616, doi:10.5194/amt-4-599-2011, 2011.

Sintermann, J., Schallhart, S., Kajos, M., Jocher, M., Bracher, A., Münger, A., Johnson, D., Neftel, A., and Ruuskanen, T.: Trimethylamine emissions in animal husbandry, Biogeosciences, 11, 5073-5085, doi:10.5194/bg-11-5073-2014, 2014.

Sipilä, M., Sarnela, N., Jokinen, T., Junninen, H., Hakala, J., Rissanen, M. P., Petäjä, T., and Worsnop, D. R.: Bisulphatecluster based atmospheric pressure chemical ionization mass spectrometer for ultra-high sensitivity $(10 \mathrm{ppq})$ detection of atmospheric amines: proof-of-concept and first ambient data from boreal forest, Atmos. Meas. Tech. Discuss., 8, 3667-3696, doi:10.5194/amtd-8-3667-2015, 2015.

Smith, B. N. and Meeuse, B. J. D.: Production of volatile amines and skatole at anthesis in some arum Lily species, Plant Physiol., 41, 343-347, doi:10.1104/pp.41.2.343, 1966.

Smith, J. N., Barsanti, K. C., Friedli, H. R., Ehn, M., Kulmala, M., Collins, D. R., Scheckman, J. H., Williams, B. J., and McMurry, P. H.: Observations of aminium salts in atmospheric nanoparticles and possible climatic implications, P. Natl. Acad. Sci. USA, 107, 6634-6639, doi:10.1073/pnas.0912127107, 2010.

Smith, T. A.: The occurrence, metabolism and functions of amines in plants, Biol. Rev., 46, 201-241, doi:10.1111/j.1469185X.1971.tb01182.x, 1971.

Smith, T. A.: Recent advances in the biochemistry of plant amines, Phytochemistry, 14, 865-890, 1975.
Spracklen, D. V., Jimenez, J. L., Carslaw, K. S., Worsnop, D. R., Evans, M. J., Mann, G. W., Zhang, Q., Canagaratna, M. R., Allan, J., Coe, H., McFiggans, G., Rap, A., and Forster, P.: Aerosol mass spectrometer constraint on the global secondary organic aerosol budget, Atmos. Chem. Phys., 11, 12109-12136, doi:10.5194/acp-11-12109-2011, 2011.

Stein von Kamienski, E.: Untersuchungen über die flüchtigen Amine der Pflanzen: II. Mitteilung Die Amine von Blütenpflanzen und Moosen, Planta, 50, 315-330, doi:10.1007/BF01938621, 1957a.

Stein von Kamienski, E.: Untersuchungen über die flüchtigen Amine der Pflanzen: I. Mitteilung Methodik der Trennung und des Nachweises flüchtiger Amine, Planta, 50, 315-330, doi:10.1007/BF01938621, 1957b.

Stein von Kamienski, E.: Untersuchungen über die flüchtigen Amine der Pflanzen: III. Mitteilung Die Amine von Pilzen. Über den Weg der Aminbildung in Pflanzen, Planta, 50, 331-352, doi:10.1007/BF01911373, 1958.

Steiner, M.: Flüchtige Amine in Pflanzen, vol. 161 of Arbeitsgemeinschaft für Forschung des Landes Nordrhein-Westfalen, Springer Fachmedien, Wiesbaden, 1966.

Steiner, M. and Hartmann, T.: Über Vorkommen und Verbreitung flüchtiger Amine bei Meeresalgen, Planta, 79, 113-121, doi:10.1007/BF00390154, 1968.

Steiner, M. and Löffler, H.: Stickstoffbasen im Eiweissabbau höherer Pflanzen, II. Histochemische Studien über Verbreitung, Verteilung und Wandel des Ammoniaks und der flüchtigen Amine, Jahr. Wiss. Bot., 71, 463-532, 1929.

Steiner, M., Hartmann, T., Dönges, D., and Bast, E.: Biosynthese flüchtiger Amine durch eine Amin-Transaminase in Blütenpflanzen, Naturwissenschaften, 54, 370-371, doi:10.1007/BF00636644, 1967.

Sutton, M. A., Pitcairn, C. E. R., and Fowler, D.: The exchange of ammonia between the atmosphere and plant-communities, Adv. Ecol. Res., 24, 301-393, 1993.

Suzuki, T.: Metabolism of Methylamine in the Tea Plant (Thea sinensis L.), Biochem. J., 132, 753-763, 1973.

Tsai, C.-J., Chen, M.-L., Ye, A.-D., Chou, M.-S., Shen, S.-H., and Mao, I.-F.: The relationship of odor concentration and the critical components emitted from food waste composting plants, Atmos. Environ., 42, 8246-8251, doi:10.1016/j.atmosenv.2008.07.055, 2008.

van Neste, A., Duce, R. A., and Lee, C.: Methylamines in the marine atmosphere, Geophys. Res. Lett., 14, 711-714, 1987.

Vickery, H. B.: Some nitrogenous constituents of the juice of the alfalfa plant IV. The betaine fraction, J. Biol. Chem., 65, 81-89, 1925.

Vickery, H. B.: The nitrogenous constituents of green plants, Annu. Rev. Biochem., 1, 611-617, doi:10.1146/annurev.bi.01.070132.003143, 1932.

Vickery, R.: A Dictionary of Plant-Lore, Oxford paperback reference, Oxford University Press, Oxford, New York, 1995.

Vitousek, P. M., Hättenschwiler, S., Olander, L., and Allison, S.: Nitrogen and nature, Ambio, 31, 97-101, doi:10.1579/0044-744731.2.97, 2002.

Wang, X. C. and Lee, C.: Sources and distribution of aliphaticamines in salt marsh sediments, Org. Geochem., 22, 1005-1021, 1994. 
Wang, Y., Zhang, J., Marcotte, A. R., Karl, M., Dye, C., and Herckes, P.: Fog chemistry at three sites in Norway, Atmos. Res., 151, 72-81, doi:10.1016/j.atmosres.2014.04.016, 2015.

Westervelt, D. M., Pierce, J. R., and Adams, P. J.: Analysis of feedbacks between nucleation rate, survival probability and cloud condensation nuclei formation, Atmos. Chem. Phys., 14, 55775597, doi:10.5194/acp-14-5577-2014, 2014.

Wicke, W.: Beobachtungen an Chenopodium vulvaria über die Ausscheidung von Trimethylamin, Annalen der Chemie und Pharmacie, 124, 338-340, doi:10.1002/jlac.18621240213, 1862.

Wink, C. and Hartmann, T.: Properties and Subcellular Localization of L-Alanine: Aldehyde Aminotransferase: Concept of an Ubiquitous Plant Enzyme Involved in Secondary Metabolism, Z. Naturforsch., 36c, 625-632, 1981.

Woodcock, T. S., Larson, B. M., Kevan, P. G., Inouye, D. W., and Lunau, K.: Flies and flowers II: Floral attractants and rewards, J. Poll. Ecol., 12, 63-94, 2014.

Yan, F., Schubert, S., and Mengel, K.: Soil pH increase due to biological decarboxylation of organic anions, Soil Biol. Biochem., 28, 617-624, doi:10.1016/0038-0717(95)00180-8, 1996.

You, Y., Kanawade, V. P., de Gouw, J. A., Guenther, A. B., Madronich, S., Sierra-Hernández, M. R., Lawler, M., Smith, J. N., Takahama, S., Ruggeri, G., Koss, A., Olson, K., Baumann, K., Weber, R. J., Nenes, A., Guo, H., Edgerton, E. S., Porcelli, L., Brune, W. H., Goldstein, A. H., and Lee, S.-H.: Atmospheric amines and ammonia measured with a chemical ionization mass spectrometer (CIMS), Atmos. Chem. Phys., 14, 12181-12194, doi:10.5194/acp-14-12181-2014, 2014.
Yu, F. and Luo, G.: Modeling of gaseous methylamines in the global atmosphere: impacts of oxidation and aerosol uptake, Atmos. Chem. Phys., 14, 12455-12464, doi:10.5194/acp-1412455-2014, 2014.

Yu, H., McGraw, R., and Lee, S.-H.: Effects of amines on formation of sub-3 nm particles and their subsequent growth: multicomponent nucleation with amines, Geophys. Res. Lett., 39, L02807, 1-5, doi:10.1029/2011GL050099, 2012.

Yu, Z., Zhang, Q., Kraus, T. E. C., Dahlgren, R. A., Anastasio, C., and Zasoski, R. J.: Contribution of amino compounds to dissolved organic nitrogen in forest soils, Biogeochemistry, 61, 173-198, 2002.

Zhao, J., Smith, J. N., Eisele, F. L., Chen, M., Kuang, C., and McMurry, P. H.: Observation of neutral sulfuric acid-amine containing clusters in laboratory and ambient measurements, Atmos. Chem. Phys., 11, 10823-10836, doi:10.5194/acp-1110823-2011, 2011.

Zollner, J. H., Glasoe, W. A., Panta, B., Carlson, K. K., McMurry, P. H., and Hanson, D. R.: Sulfuric acid nucleation: power dependencies, variation with relative humidity, and effect of bases, Atmos. Chem. Phys., 12, 4399-4411, doi:10.5194/acp-124399-2012, 2012. 